\title{
Training Preceptors of Obstetrics-Gynecology Residents through the One-minute Preceptor Model
}

\section{Capacitando preceptores de residentes em Ginecologia e Obstetrícia pelo modelo One-minute Preceptor}

\author{
Michelle Araújo Machado ${ }^{1}$ Elaine Lira Medeiros ${ }^{1}{ }^{(1)}$ \\ ${ }^{1}$ Department of Gynecology, Universidade Federal do Rio Grande do \\ Norte, Natal, Rio Grande do Norte, RN, Brazil \\ Address for correspondence Michelle Araújo Machado, Universidade \\ Federal do Rio Grande do Norte, Avenida Senador Salgado Filho, \\ Rev Bras Ginecol Obstet 2021;43(8):622-626. \\ 3.000, Lagoa Nova, Natal, Rio Grande do Norte, RN, Brazil \\ (e-mail: michellemachado1978@gmail.com).
}

\begin{abstract}
Keywords

- preceptorship

- training courses

- internship and residency

- formative feedback

- medical education
\end{abstract}

\section{Resumo}

Objective To analyze the effect of the One-minute Preceptor model for preceptors who work at the emergency department of a maternity teaching hospital.

Methods A quantitative intervention study conducted with Obstetrics and Gynecology residency preceptors at a maternity teaching hospital in northeastern Brazil. Three stages were performed: 1 ) a preintervention survey with the residents; 2 ) planning and execution of a pedagogical training course for the preceptors, which involved a lecture and a dramatization about the One-Minute Preceptor model; and 3) thirty days after the intervention, the residents answered another survey about the model and its repercussions and advantages.

Results The preintervention assessment with the residents showed that $91.7 \%$ agreed that there were discrepancies regarding the teaching model among the preceptors. After the training, all preceptors agreed that the model engages the student in the decision-making process, and that they would apply it to their routine. The postintervention results showed that $95.8 \%$ agreed that the model is more inviting than traditional teaching approaches. There was a perception of improvement in learning among $70.9 \%$ of the residents. In addition, the present study found a significant change in feedback before and after implementing the model, from $20.8 \%$ to $66.7 \%$.

Conclusion The training course of preceptors in the One-Minute Preceptor model proved to be efficient in providing formative feedback to residents in the emergency department of a maternity school. Further studies are needed to assess the consolidation of the methodology in the long term.

Objetivo Analisar o efeito de uma capacitação no modelo One-Minute Preceptor para preceptores que atuam no setor de urgência de uma maternidade escola.

Métodos Estudo de intervenção, quantitativo, realizado com preceptores de residência em Ginecologia e Obstetrícia de uma maternidade escola do Nordeste received

September 8, 2020

accepted

July 23, 2021
DOI https://doi.org/

$10.1055 / \mathrm{s}-0041-1735230$ ISSN $0100-7203$
(C) 2021. Federação Brasileira de Ginecologia e Obstetrícia. All rights reserved.

This is an open access article published by Thieme under the terms of the Creative Commons Attribution License, permitting unrestricted use, distribution, and reproduction so long as the original work is properly cited. (https://creativecommons.org/licenses/by/4.0/)

Thieme Revinter Publicações Ltda., Rua do Matoso 170, Rio de Janeiro, RJ, CEP 20270-135, Brazil 


\section{Palavras-chave \\ - preceptoria \\ - cursos de capacitação \\ - internato e residência \\ - feedback formativo \\ - educação médica}

brasileiro. Três etapas foram realizadas: 1) questionário pré-intervenção com os residentes; 2) planejamento e execução de um curso de capacitação pedagógica para os preceptores, que envolveu uma aula expositiva dialogada e dramatização sobre o modelo One-Minute Preceptor; e 3) trinta dias após a intervenção, os residentes responderam a outro questionário sobre a aplicação, a repercussão e as vantagens do modelo.

Resultados $\mathrm{Na}$ avaliação de ensino dos residentes pré-intervenção, os resultados mostraram que $91,7 \%$ concordaram que existiam divergências quanto a metodologia de ensino entre os preceptores. Após a capacitação, todos os preceptores concordaram que o método envolve o aluno no processo de tomada de decisão, e que aplicariam o método na sua rotina no setor de urgência. Os resultados pós-intervenção mostraram que $95,8 \%$ concordam que o modelo é mais atratente do que as abordagens de ensino tradicionais. Para $70,9 \%$ dos residentes, houve uma percepção de melhora da aprendizagem; além disso, observou-se uma mudança siginificativa do recebimento de feedback antes e após a implantação do modelo, de $20,8 \%$ para $66,7 \%$.

Conclusão A capacitação de preceptores no modelo One Minute Preceptor mostrou-se eficiente no fornecimento de feedback formativo aos residentes no setor de urgência de uma maternidade escola. Novos estudos serão necessários para avaliar a consolidação da metodologia em longo prazo.

\section{Introduction}

Residency is considered the gold standard of specialization programs, and its purpose is to improve the professional competency acquired during the undergraduate medicine course. In addition to teaching knowledge and skills, it also enhances the students' relationship attributes, postures, and attitudes needed to achieve medical professionalism. The resident learns through a wide range of techniques, thus achieving professional quality in its fullness. ${ }^{1-4}$

The figure of the preceptor has been a part of medical education for many years. And if medical residency has been documented since 1889 , learning from more experienced doctors has been recognized since the dawn of medicine, ${ }^{4}$ for they provide guidance, support, teaching, and knowledge of their experiences. ${ }^{5}$

Despite having an extremely important role in the training of medical students, residency preceptors have little experience with pedagogical training. Without an adequate follow-up from them, students are left loose and unassisted; thus, exposed to poor practices that will have a negative influence on their education. ${ }^{6}$ When exercising preceptorship, the doctor must master not only clinical knowledge, but they must be able to transform field experience into teaching, in addition to conveying pedagogical knowledge. ${ }^{7}$

Regarding the pedagogical knowledge needed to train a preceptor, gaps are evident. ${ }^{8-10}$ On the other hand, highereducation institutions have been pressured to change the way these professionals are qualified, and are currently meeting the demand to form instructors who can transform realities. The guidelines for medical syllabi corroborate this idea of critical and reflective teaching through the implementation of methodologies that encourage students to learn and to reflect upon social reality. ${ }^{11}$
Active learning, which emerged in the 1960s, is a teaching-learning strategy based on problematization to reach and motivate the student through keen involvement in their training, while the preceptor acts only as a facilitator. Its use can be the solution to develop student autonomy, forming creative, reflective, and independent professionals. ${ }^{12,13}$

In 1992, researchers from the Department of Family Medicine at the University of Washington ${ }^{14}$ introduced, in outpatient clinics, a new model of preceptorship which could also be used in emergency rooms and wards. The model's theory provides the preceptor with the ability to convey valuable medical information to their students in a fast and effective manner, and to comprehend the particularities of each student. Called One-Minute Preceptor (OMP), this medical teaching model was developed to be used when a student or resident, after assessing a clinical case, requests the assistance of their preceptor to solve problems. It consists of five fundamentals steps (microskills): 1) get a commitment: getting a commitment from the learner about what is going on with the patient, asking them to state the probable diagnoses; 2) probe for supporting evidence: probe the learner for their underlying reasoning, encouraging them to state aspects regarding the differential diagnosis; 3 ) teach general rules: based on the answers to steps 1 and 2, teach general principles about the clinical case; 4) reinforce what was done right: provide positive and formative feedback to the learner; and 5) correct mistakes: correct errors for future performance. $^{14}$

Some authors ${ }^{15}$ suggest the OMP model as a framework for an efficient and precise preceptorship, which enables learning in limited time due to patient-care demands. Considering the relevance of this issue, the present study aimed to analyze the effect of the OMP model on preceptors who 
work at the emergency department of a maternity teaching hospital in northeastern Brazil.

\section{Methods}

The present was a cross-sectional study associated with the Obstetrics and Gynecology (OBG-GYN) residency program at a maternity teaching hospital in the city of Natal, Brazil. Data collection occurred between August and November 2019. Of the 28 eligible preceptors who worked at the Emergency Department, 15 volunteered to participate in a training course. As for the residents, 24 out of 28 answered surveys before and after the educational intervention alongside with the preceptors.

Initially, a face-to-face survey was applied to OB-GYN residents to identify their sociodemographic characteristics, the year of residence they were attending, questions regarding the teaching methods used by the preceptors, the feedback, and their impressions on the quality of teaching (questionnaire A).

The training course was held in October 2019, at the maternity auditorium; it lasted 3 hours, and was taught during the night shift. A badge containing the OMP steps on the back was given to each tutor.

First, there was a seminar on the OMP addressing the following topics: 1) difficulties encountered while exercising preceptorship; 2) the need for educational training courses; 3) division between teaching and practice in a high-flow environment; 4) professional competency versus pedagogical competency; 5) comparison between the traditional and active methodologies; and 6) presentation of the OMP, step by step. Questions and further discussions were held at the end of the lecture.

Later, role-playing was performed by a fellow and a resident; both had previously been trained by the researcher. The case study was about severe preeclampsia, and it was managed in two contrasting ways: the first one, by an "inadequate" tutor, using the traditional approach, without considering the student's autonomy, and the second, using the OMP. After the role-play, some preceptors were invited to reproduce case discussions using the OMP model.

In the end, a satisfaction survey (questionnaire B) was applied to assess the duration of the course, the teaching method, the applicability of the OMP model, and the degree of comfort in providing feedback; the survey also contained a blank space for suggestions and critiques. Thirty days after the training, another survey (questionnaire C) was answered, in person, by the residents about their perceptions of the OMP and its applicability during shifts.

At first, a database was created to organize the data. Next, tables of absolute and relative frequencies were built to characterize the residents regarding their sociodemographic characteristics and to analyze questionnaires A, B, and C, whose alternatives were planned according to the Likert scale. ${ }^{16}$ For the data analysis, we used the Microsoft Office Excel (Microsoft Corp., Redmond, WA, US) software, version 2016, and the McNamer test. The second one was used for the quantitative analysis of the paired variables to verify the association between two categorical variables (receiving feedback before and after). A significance level of 5\% was adopted for all tests. The statistical analysis was performed using the Statistical Package for the Social Sciences (IBM SPSS Statistics for Windows, IBM Corp., Armonk, NY, US) software, version 21.

The study was approved by the institutional Ethics in Research Committee under protocol number 3.483.115, CAAE 17211319.6.0000.5292, in August 2019. A consent form was provided to the preceptors and residents who took part in the study.

\section{Results}

The results of the survey results are presented in three subtopics: the first one contains data from the residents before the intervention; the second one contains information from the preceptors; and the third contains data from residents after the training with the preceptors.

\section{Preintervention: The Resident's Perspective on the Teaching-Learning Process}

The study identified that $91.7 \%(n=22)$ of the residents completely or partially agreed that there were differences in the methodology used by the preceptors: $54.2 \%(n=13)$ agreed completely, and $37.5 \%(n=9)$, partially. We noted that $62.5 \%$ $(n=15)$ of the residents partially agreed that the central figure in the teaching-learning process was the preceptor-patient relationship. Regarding the stimulation of clinical reasoning, $71 \%(n=17)$ of the residents felt they were partially $(41.8 \%)$ or totally (29.2\%) active in the teaching-learning process. On the other hand, $75 \%(n=18)$ disagreed, totally ( $46 \%)$ or partially (29\%), about receiving feedback. However, $70.8 \%(n=17)$ rated the quality of the teaching as good.

\section{Intervention: Training Preceptors in the OMP Model} The preceptors were predominantly female (93.3\%) and associated with the state-owned Empresa Brasileira de Serviços Hospitalares (Brazilian Hospital Services Company, EBSERH, in Portuguese) (80\%). They joined the training on the OMP model and subsequently evaluated the intervention. They indicated that the duration of the course was adequate, the presentation was satisfactory, and the roleplaying was easy to understand.

The data showed that $86.7 \%(n=13)$ of the preceptors agreed that the OMP model involves the student in the decision-making process, and 93.3\% $(n=14)$ agreed, totally (60\%) or partially (33.3\%), that the OMP would streamline the service flow. All participants indicated that they would start applying the model to their routines.

As for the provision of feedback, after the training, 86.7\% $(n=13)$ of the preceptors answered that they felt comfortable, and only $13.3 \%(n=2)$ reported they felt uncomfortable doing it. We also observed that these preceptors did not provide feedback regularly due to the lack of training and did not undermine the residents' self-esteem.

At the end of the satisfaction survey, 7 (25\%) preceptors suggested increasing the number of on-call staff to make the application of the model easier, the provision of ongoing education for them, a unification of their conduct, more time to discuss the cases, and issues regarding team recycling. 
Table 1 Perception of the residents on receiving feedback before and after the intervention using the McNamer test with a significance level of $5 \%$

\begin{tabular}{llll}
\hline Receiving feedback & Before & After & Total \\
\cline { 2 - 4 } & $\mathbf{n}(\%)$ & $\mathbf{n ~ ( \% )}$ & $\mathbf{n}(\%)$ \\
\hline Totally disagree & $11(45.83)$ & $02(8.33)$ & $13(27.07)$ \\
Partially disagree & $07(29.17)$ & $03(12.50)$ & $10(20.83)$ \\
Indifferent & $01(4.17)$ & $03(12.50)$ & $04(8.34)$ \\
Partially agree & $04(16.67)$ & $10(41.67)$ & $14(29.18)$ \\
Totally agree & $01(4.16)$ & $06(25.00)$ & $07(14.58)$ \\
Total & $24(100.00)$ & $24(100.00)$ & $48(100.00)$ \\
\hline
\end{tabular}

\section{Postintervention: The Perspective of the Residents after the Training}

After the training, $66.67 \%(n=16)$ of the residents agreed that the cases started to be discussed using the OMP model. - Table 1 shows the result of the McNamer test used to assess the frequencies of two related samples. A statistically significant change was noted for the feedback received by the residents before and after the training: from $20.8 \%$ to $66.7 \%(p=0.021)$ (-Fig. 1$)$.

A total of $33(95.8 \%)$ residents also agreed that the OMP is a more interesting model than other traditional teaching methods, and only $4.2 \%(n=1)$, totally disagreed with the OMP. Finally, $70.9 \%$ of the residents completely agreed that there was an improvement in teaching and learning using the OMP model.

\section{Discussion}

The present study showed that the preceptors who conducted the training on the OMP recognized that the model engages the student in the decision-making process and improves the service flow. All preceptors agreed to incorporate the model into their routines.

Likewise, an American study ${ }^{17}$ conducted in 2018 offered workshops on the OMP to 294 staff physicians and 98 residents from 21 different medical specialties and subspecialties, at 16 different teaching hospitals, and found that $97 \%$ of participants would use the method frequently, even daily. It also established that the presentation and discussion of the model followed by role-playing, the same resources used in our study, can be effective to instruct the participants on the use of the OMP.

A recent article ${ }^{18}$ from a Nursing college in Washington reported training 58 preceptors using methodologies focused on clinical teaching, and, among them, the OMP model. All participants rated the steps of the method as useful or very useful. Therefore, the authors pointed out that training preceptors in evidence-based and efficient strategies, such as the OMP, is feasible and effective.

A study ${ }^{19}$ performed 2019 in the state of Pernambuco, Brazil, identified that, after training preceptors using the OMP, the implementation of the model for physiotherapy

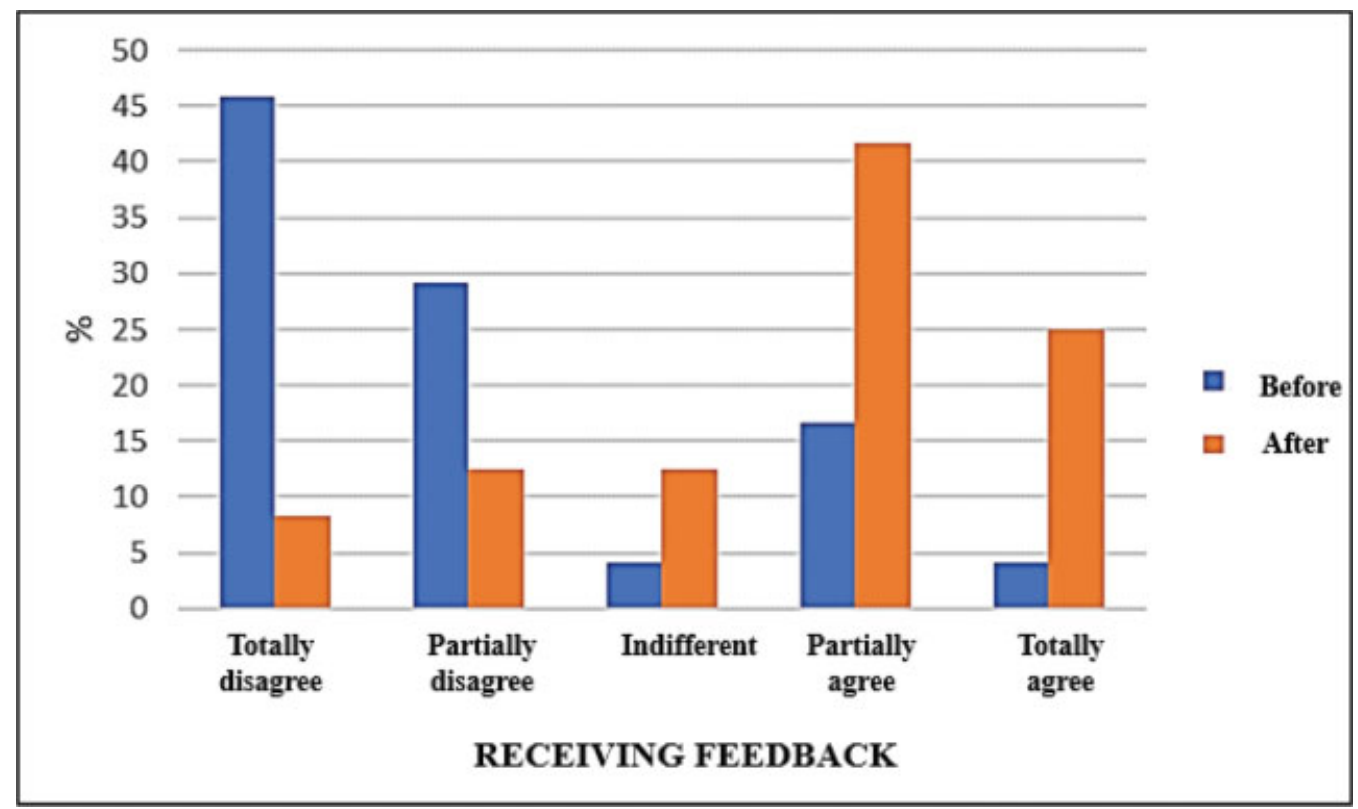

Fig. 1 Perception of the residents on receiving feedback before and after the intervention. 
students was positively analyzed by both preceptors and students. The study also showed that preceptors trained using the method had improved regarding the provision of feedback and the teaching of critical reasoning to students.

The relevant data found by the present study was the significant increase in the provision of feedback after the intervention, thus contributing to improve the teachinglearning process. The residents considered feedback an important learning tool, and they valued teachers who knew how to provide it effectively.

A research ${ }^{20}$ performed with interns and residents $(n=3,471)$ of the outpatient clinics of five medical schools in Ontario, Canada, investigated the location characteristics and preceptor behaviors that contributed to the students' learning. It was then identified that 95\% considered that providing feedback constructively is an essential attribute of the preceptor, taking second place among 36 other teaching skills listed, being surpassed only by the ability to be open to questions.

Nonetheless, a study ${ }^{21}$ performed in Singapore, using a method similar to ours, involved 37 preceptors who were trained in workshops on OMP and 34 dentistry residents who evaluated them. The perceptions about clinical teaching were assessed before and after the training, and the authors concluded that the short duration of the training impaired the quantity and quality of the education. Thus, this study showed that a single workshop for faculty members did not substantially improve the perceptions of the residents regarding the quality or quantity of the education, which indicates that training should be ongoing.

\section{Conclusion}

There was good acceptability of the OMP model by the preceptors. Moreover, the model was inserted in a standardized manner in the emergency work routine of the Obstetrics and Gynecology Department, as well as in the case discussions of the residents, who reported more autonomy provided by the model. In addition, there was an increase in the stimulus to clinical reasoning and to provide feedback, which were previously weak, and started to be provided regularly by the preceptors. Therefore, training preceptors on the OMP showed to be an important, viable, and effective strategy. Further training and investigations are needed to assess how this method develops in the long term.

\section{Contributions}

All authors were involved in the design and interpretation of the analyses; they contributed to the writing, and read and approved the final manuscript.

\section{Conflict of Interests}

The authors have no conflict of interests to declare.

\section{References}

1 Ministério da Educação Secretaria de Ensino Superior. Residência Médica Latu Sensu. Brasília, DF: MEC; 2012
2 Sampaio SA. A implantação da residência médica no hospital das clínicas: 40 anos de história. Estud FUNDAP.. 1984;1:4-32

3 Botti SH. O papel do preceptor na formação de médicos residentes: um estudo de residências em especialidades clínicas de um hospital de ensino [tese]. Rio de Janeiro: Escola Nacional de Saúde Pública Sergio Arouca; 2009

4 Martins LA. Residência médica: estresse e crescimento. São Paulo: Casa do Psicólogo; 2005

5 Macedo CG. Apresentação. In: Almeida M, Feuerwerker L, Llanos M. organizadores A educação dos profissionais de saúde da América Latina: teoria e prática de um movimento de mudança. São Paulo: Hucitec; 1999:9-11

6 Missaka H, Ribeiro VM. A preceptoria na formação médica: o que dizem os trabalhos nos congressos Brasileiros de educação médica 2007-2009. Rev Bras Educ Med. 2011;35(03):303-310. Doi: 10.1590/S0100-55022011000300002

7 Ribeiro KR, Prado ML. A prática educativa dos preceptores nas residências em saúde: um estudo de reflexão. Rev Gaúcha Enferm. 2014;35(01):161-165. Doi: 10.1590/1983-1447.2014. 01.43731

8 Rocha HC, Ribeiro VB. Curso de formação pedagógica para preceptores do internato médico. Rev Bras Educ Med. 2012;36(03): 343-350. Doi: 10.1590/S0100-55022012000500008

9 Afonso DH, Silveira LM. Os desafios na formação de futuros preceptores no contexto de reorientação da educação médica. Rev HUPE.. 2012;11(Suppl 1):82-86

10 Silva VC, Viana LO, Santos CR. A preceptoria na graduação em enfermagem: uma revisão integrativa da literatura. Journal of Research: Fundamental Care Online. 2013;5(05):20-28

11 Ministério da Educação Conselho Nacional de Educação Câmara de Educação Superior Resolução CNE/CES No. 3, de 20 de junho de 2014. Institui diretrizes curriculares nacionais do curso de graduação em medicina. Diário Oficial da União Seç.. 2014;1:8-11

12 Araújo TA, Vasconcelos AC, Pessoa TR, Forte FD. Multiprofissionalidade e interprofissionalidade em uma residência hospitalar: o olhar de residentes e preceptores. Interface (Botucatu). 2017;21 (62):601-613. Doi: 10.1590/1807-57622016.0295

13 Farias LM. Manual do estágio curricular do curso de graduação em Enfermagem. Brasília, DF: Fundação de Ensino e Pesquisa em Ciências da Saúde/Escola Superior de Ciências da Saúde; 2015

14 Neher JO, Gordon KC, Meyer B, Stevens N. A five-step "microskills" model of clinical teaching. J Am Board Fam Pract. 1992;5(04):419-424

15 Chemello D, Manfroi WC, Machado CL. O papel do preceptor no ensino médico e o modelo preceptoria em um minuto. Rev Bras Educ Med. 2009;33(04):664-669. Doi: 10.1590/S0100-55022009000400018

16 Likert R. A technique for the measurement of attitudes. Arch Psychol. 1932;22(140):1-55

17 Servey J, Wyrick K. Teaching clinical precepting: a faculty development workshop using role-play. MedEdPORTAL. 2018; 14:10718. Doi: 10.15766/mep_2374-8265.10718

18 Fincham SJ, Smith T, Purath J. Implementation of an educational program to improve precepting skills. J Am Assoc Nurse Pract. 2019;33(04):331-337. Doi: 10.1097/JXX.0000000000000326

19 Pimentel CM. Análise da implementação do modelo de ensino one minute preceptor na vivência da prática profissional de estudantes de fisioterapia de uma faculdade do Nordeste brasileiro [dissertação]. Recife: Faculdade Pernambucana de Saúde; 2019

20 Schultz KW, Kirby J, Delva D, Godwin M, Verma S, Birtwhistle R, et al. Medical Students' and Residents' preferred site characteristics and preceptor behaviours for learning in the ambulatory setting: a cross-sectional survey. BMC Med Educ. 2004;4:12. Doi: 10.1186/1472-6920-4-12

21 Ong MM, Yow M, Tan J, Compton S. Perceived effectiveness of oneminute preceptor in microskills by residents in dental residency training at National Dental Centre Singapore. Proc Singapore Healthcare.. 2017;26(01):35-41. Doi: 10.1177/2010105816666294 